\title{
Ehma Ainun Nadjib and a Movement from the Darkness to the Light
}

\author{
Karim \\ University of Amsterdam
}

\begin{abstract}
After two decades of Indonesia's 1998 reformasi, a rapid process of transformation has been achieved in many different aspects of social life. Democratization, freedom of speech, and progressive economic development have become the main features of 'enlightenments' of post-authoritarian era. At the same time, it is surprising to note that the 'tradition' of KKN, the Indonesian acronym of corruption, collusion nepotism used to be addressed Soeharto's dictatorship regime, remains unchanged. In response to this paradox of reform, Ehma Ainun Nadjib (Cak Nun), Indonesian Muslim Intellectual who engaged since the very beginning reform process, initiated Maiyah movement. This new form of socio-religious movement is based on his creative writing activities that have been produced more than 70 books, countless essays and poetry, and a wide variety of community engagements. Together with Kiaikanjeng, a fusion orchestra combining Javanese gamelan and modern musical instruments, he has been successfully promoting religious tolerance, urging deconstructive methods of interpreting religious texts, and initiating a unique way of community empowerment using music and theatrical performances around Indonesia and across the globe. Their performances in London, Berlin, Helsinki, Amsterdam, Rome, Cairo, Rabat, Melbourne, Kuala Lumpur, and many other parts of the world have not only left the 'sacred music' they played as an inspiration of minaddulumati ilannur (from the darkness to the light), but also created a new horizon of understanding the very basic principle of humanity, Maiyah meaning 'togetherness'. Drawing from ethnographic research in two Maiyah circles in two different urban settings of Surabaya and Yogyakarta Indonesia, this paper explores Cak Nun's legacy in offering new 'lights' of bottom-up aspiration of nationalism through what he calls Indonesia adalah Bagian dari Desa Saya (Indonesia is part of my village).
\end{abstract}

Keywords: Maiyah Movement; reform; religious tolerance; togetherness; nationalism 